\title{
Plant-Parasitic Nematodes Infecting Grapevine in Southern Spain and Susceptible Reaction to Root-Knot Nematodes of Rootstocks Reported as Moderately Resistant
}

\author{
Daniel Téliz, Instituto de Fitosanidad, Colegio de Postgraduados,56230 Montecillo, Texcoco, Mexico; Blanca B. \\ Landa, Instituto de Agricultura Sostenible (IAS), Consejo Superior de Investigaciones Científicas (CSIC), Apdo. \\ 4084, 14080 Córdoba, Spain, and Escuela Técnica Superior de Ingenieros Agrónomos y de Montes (ETSIAM), Uni- \\ versidad de Córdoba (UCO), Edificio C4- "Celestino Mutis", Carretera de Madrid Km 396, Campus de Rabanales, \\ 14071 Córdoba, Spain; Hava F. Rapoport, IAS-CSIC; Fernando Pérez Camacho, ETSIAM-UCO; Rafael M. \\ Jiménez-Díaz, ETSIAM-UCO and IAS-CSIC; and Pablo Castillo, IAS-CSIC
}

\begin{abstract}
Téliz, D., Landa, B. B., Rapoport, H. F., Pérez Camacho, F., Jiménez-Díaz, R. M., and Castillo, P. 2007. Plant-parasitic nematodes infecting grapevine in southern Spain and susceptible reaction to root-knot nematodes of rootstocks reported as moderately resistant. Plant Dis. 91:1147-1154.

Incidence and nematode population densities of plant-parasitic nematodes were determined in 64 samples of soil and grapevine roots collected from commercial vineyards in southern Spain between October 2003 and May 2005. In addition, a histopathological study was done of rootstock roots naturally infected by root-knot nematodes (Meloidogyne spp.). Nematodes infecting the rootstocks were identified according to conventional procedures, and the Meloidogyne spp. were furthermore identified by sequence characterized amplified region-polymerase chain reaction (SCAR-PCR) and isozyme esterase analyses. The most important plant-parasitic nematodes detected, in order of decreasing frequency of total soil infestation and root infection (percentage of samples), were Mesocriconema xenoplax (34.4\%), Meloidogyne incognita (26.6\%), Meloidogyne javanica (14.1\%), Xiphinema index (12.5\%), Xiphinema italiae (10.9\%), Pratylenchus vulnus (6.3\%), and Meloidogyne arenaria (1.6\%). No disease symptoms were observed on aboveground plant parts of the infected grapevines, except for plants in some fields where soil was infested with the virus-vector nematodes $X$. index and $X$. italiae. Those grapevines showed a yellow mosaic pattern in leaves early in the growing season and the internode shortening characteristic of infections by Grapevine fanleaf virus. Rootstocks infected by root-knot nematodes (Meloidogyne spp.) showed distorted feeder roots and large- to moderatesized root galls, present either singly or in clusters. Histopathology of galled roots showed a typical susceptible response to infection by root-knot nematodes: cellular alterations were induced in the cortex, endodermis, pericycle, and vascular system, including giant-cell formation and severe distortion of vascular tissues. Most Meloidogyne egg masses ocurred on the surface of the galled root tissues, a position that could facilitate dispersion of the nematode eggs and juveniles and the occurrence of secondary infections. Some of the grapevine rootstocks surveyed in this study (Paulsen 1103, Richter 110, Rupestris du Lot, and SO4) had previously been reported to be resistant to Meloidogyne spp.; however, the population densities of these nematodes found in soil and roots sampled in the present study, as well as the compatible host-parasite relationship revealed by histopathology, indicate a susceptible response to Meloidogyne spp. from southern Spain.
\end{abstract}

Additional keywords: dagger nematodes, pin nematodes, ring nematodes, root-lesion nematodes, Vitis spp.

Grapevine (Vitis vinifera) production for wine and table grapes is one of the most extensive fruit crop agricultural systems worldwide. $V$. vinifera is native to Asia Minor and the Caucasus region, was dis-

Corresponding author: P. Castillo

E-mail: ag1cascp@uco.es

* The $\boldsymbol{e}$-Xtra logo stands for "electronic extra" and indicates that Figures 2 and 3 appear in color in the online edition.

Accepted for publication 6 April 2007.

doi:10.1094/PDIS-91-9-1147

(C) 2007 The American Phytopathological Society root-knot (Meloidogyne spp.), root-lesion (Pratylenchus spp.), citrus (Tylenchulus semipenetrans), and ring (Mesocriconema spp.) nematodes $(6,14,30,31,34)$. Rootknot nematodes, especially Meloidogyne arenaria, $M$. incognita, and $M$. javanica, cause serious root damage in sandy soils under the mild temperatures that prevail in most grapevine-growing areas in California, the Mediterranean Basin, and South Africa $(3,6,28,32)$. M. hapla predominates in the cooler areas of Southern Australia and Hungary $(20,38)$, M. ethiopica parasitizes grapevines in Chile (7), and M. hispanica and $M$. nataliei infect grapevines in South Africa (22) and Michigan (5), respectively.

Pathogenicity tests under controlled conditions have demonstrated the potential of most of these nematodes to damage grapevines (6). The extent of yield losses caused by plant-parasitic nematodes is both variable and difficult to determine. Stirling et al. (39) estimated a 7\% yield loss by root-knot nematodes in Australia, while Brown et al. (6) found a $20 \%$ production loss in California (6). Knowledge of the distribution and extent of damage due to plant-parasitic nematodes in grapevine fields in southern Spain is limited mainly to studies of nematode vectors of plant viruses $(35,43)$.

Plant-parasitic nematodes, as well as soilborne fungi and phylloxera root pest (Daktulosphaira vitifoliae), are managed primarily by the use of resistant rootstocks. Resistant grapevine rootstocks are used to limit damage caused by root-knot nematodes in grapevines grown on sandy soil worldwide (6). However, the long-term use of the resistant rootstocks can impose strong selection pressure on the root-knot nematode population. Thus, nematodes able to reproduce and adapt to the roots of a resistant or moderately resistant rootstock will give rise to new pathotypes, making that rootstock useless for control of the nematode (24).

Information is scarce concerning the host-parasite relationships in natural infections by root-knot nematodes of grapevine rootstocks commonly reported to have some resistance to plant-parasitic nematode species, especially to Meloidogyne 
spp. Histopathological studies in naturally infected rootstock roots reveal important details about the capacity of the nematode to enter, develop, and reproduce in the root tissues and thus indicate the compatible or incompatible nature of the nematode-plant interactions. Such knowledge, together with data on nematode population densities in soil and roots of cultivated grapevines, would be useful to viticulturalists worldwide and important to manage diseases and to lessen the reliance on nematicides. In consequence, the objectives of this study were: (i) to determine the identity, frequency, and population density of plant-parasitic nematodes infecting grapevine rootstocks growing in southern Spain, and (ii) to evaluate the host-parasite relationships in grapevine rootstocks in the case of naturally occurring infections by root-knot nematodes. To our knowledge, this is the first histopathological study of grapevine rootstocks naturally infected by root-knot nematodes.

Nematode survey. Disease surveys were undertaken in commercial vineyards in Andalusia, Southern Spain between 2003 and 2005. For that purpose, the region was divided into three geographically separated zones that include the three major wine production areas corresponding to marketing-operating "wine denomination of origin (DO) zones" Condado de Huelva DO (Huelva Province), Montilla-Moriles DO (Córdoba Province), and Jerez-XérèsSherry y Manzanilla-Sanlúcar de Barrameda DO (Cádiz Province). Sixty-four vineyards were selected, and grapevine feeder roots together with the rhizosphere and bulk soils were sampled. Samples were collected with a shovel from the upper $40 \mathrm{~cm}$ of soil of three to four plants chosen arbitrarily in each vineyard, from October 2003 to May 2005 (Table 1). The surveyed vineyards were representative of grapevines grown in southern Spain; they were selected on the basis of parameters

\section{MATERIALS AND METHODS}

indicative of their commercial importance, including the total growing area and geographical distribution of cultivars, rootstock, and crop age. The 64 root samples included several rootstocks (Table 1), as well as unknown accessions of Vitis berlandieri (1 sample) and Vitis riparia (1 sample).

Frequency of infestation and population density of plant-parasitic nematodes were determined. The frequency of infestation was calculated as the percentage of samples in which a nematode species was diagnosed. Nematode population densities in root and soil were assessed for each sample and calculated as the average of the soil and root counts. A 5-g root subsample was washed free of soil, weighed, and used to extract nematodes by the macerationcentrifugation procedure (9). When galled roots were found, representative roots were selected for histopathological studies and to determine the number of Meloidogyne eggs present. Eggs were collected from the galled roots by blending in a $0.5 \% \mathrm{NaOCl}$ solution for $4 \mathrm{~min}$ (17). Nematodes from the soil were extracted from a $100-\mathrm{cm}^{3}$ subsample using the centrifugal-flotation method (9). The nematodes were then fixed in $4 \%$ formaldehyde, counted, and identified by morphological traits to genus. Selected adult specimens of separate genera were processed to glycerin (37) and mounted on microscope slides for species identification.

Meloidogyne species were identified by perineal pattern morphology. For each Meloidogyne population, at least 20 perineal patterns were prepared and examined (16). The root tissues were teased apart with forceps and half-spear to remove adult females. The head and neck region of the nematode was excised, and the posterior part was placed in a $45 \%$ lactic acid solution to remove all body tissues. Then, the perineal pattern was trimmed, transferred to a drop of glycerin, and processed as described by Hartman and Sasser (16). Frequency of infestation was calculated as

Table 1. Localities and grapevine rootstocks sampled in southern Spain

\begin{tabular}{llcl}
\hline Province & Locality & $\begin{array}{c}\text { No. of } \\
\text { samples }\end{array}$ & Grapevine rootstocks \\
\hline Cádiz & Chipiona & 4 & Couderc 161-49; Paulsen 1103; Richter 110; SO4 \\
& Jerez de la Frontera & 12 & $\begin{array}{l}\text { Couderc 161-49; 333 École Montpellier; } \\
\text { Millardet \& Grasset 41-B }\end{array}$ \\
& Sanlúcar de Barrameda & 4 & $\begin{array}{l}\text { Couderc 161-49; Moscatel } \\
\text { Córdoba }\end{array}$ \\
& Trebujena & 3 & Couderc 161-49 \\
& Aguilar de la Frontera & 8 & Couderc 161-49; Richter 110 \\
& Montemayor & 10 & Millardet \& Grasset 41-B; Richter 110; \\
& Montilla & & Ruggieri 140; Vitis berlandieri \\
& & 6 & Couderc 161-49; Millardet \& Grasset 41-B; \\
& Monturque & 3 & Couderc 110, Ruggeri 140 \\
& Puente Genil & 3 & Couderc 161-49; Richter 110 \\
Huelva & Almonte & 4 & Richter 110; Rupestris du Lot \\
& Bollullos del Condado & 3 & Couderc 161-49; Richter 110 \\
& Bonares & 1 & Castel 196-17 \\
& Niebla & 2 & Richter 110 \\
& Rociana & 1 & Vitis riparia \\
\hline
\end{tabular}

the percentage of samples in which a nematode species was identified.

DNA extraction, polymerase chain reaction (PCR) assays, and isozyme esterase analyses. Morphological identification of Meloidogyne species is difficult because of the need of training and experience by operators as well as intra-specific variability of morphological traits of taxonomic use (21). Consequently, the Meloidogyne spp. from this study were also identified using sequence characterized amplified region (SCAR)- PCR (44) and analysis of isozyme esterases (12). For PCR assays, total genomic DNA was extracted from at least five to eight adult females per sample according to Castillo et al. (8). PCR assays were carried out using the species-specific SCAR primer pairs Far/Rar (M. arenaria), Finc/Rinc ( $M$. incognita), and Fjav/Rjav (M. javanica) and the reaction conditions described by Zijlstra et al. (44). Amplifications were performed with a PTC 200 thermocycler (MJ Research, Bio-Rad Laboratories, Madrid, Spain). Amplification products were separated using the FlashGel system (Cambrex Bio Science Rockland, Inc., Rockland, ME, USA) by electrophoresis at $250 \mathrm{~V}$ for 5 to $7 \mathrm{~min}$. The AmpliSize 50-2,000 bp ladder (Bio-Rad) was used for electrophoresis. The assays were repeated at least twice, and always included negative controls (no DNA) and positive DNA controls from $M$. arenaria and $M$. incognita adult females from olive nurseries (27), and M. javanica adult females from potato (41), whose identity was certain.

For esterase analyses, one young egglaying female representative of those found in the samples and two egg-laying females of an $M$. javanica reference population from potato (41) were placed in microtubes containing $5 \mu \mathrm{l}$ of $20 \%$ sucrose and $1 \%$ Triton X-100 and macerated. Electrophoresis was carried out in $7 \times 8 \mathrm{~cm}$ homogeneous polyacrylamide gels, $0.75 \mathrm{~mm}$ thick, in a Mini Protean II electrophoresis unit (Bio-Rad). Gels were stained for esterases with the substrate $\alpha$-naphthyl acetate as described before (12).

Histopathology. Galled roots from naturally infected rootstocks sampled from vineyards in all three provinces were selected for histopathological studies. The roots were carefully washed free of adhering soil and debris, and individual galls and healthy root pieces were fixed in FAE (formalin:acetic acid:60\% ethanol = 2:1:17 $\mathrm{vol} / \mathrm{vol} / \mathrm{vol}$ ) for a minimum of $48 \mathrm{~h}$, dehydrated in a tertiary butyl alcohol series (7085-90-100\%), and embedded in Histosec embedding paraffin melting point 56 to $58^{\circ} \mathrm{C}$ (Merck, Darmstadt, Germany). Embedded tissues were sectioned transversely at 10 to $12 \mu \mathrm{m}$ with a rotary microtome, mounted on glass slides, stained with tannic acid, iron chloride, safranin, and fastgreen (19), and examined under a light 
microscope. Images were captured with a Leica QW5001 image processing system.

\section{RESULTS}

Nematode survey. Eighteen genera and 36 species of plant-parasitic nematodes were found associated with grapevine rootstocks in southern Spain (Table 2). Potentially damaging species included the rootknot nematodes Meloidogyne arenaria, $M$. incognita, $M$. javanica, ring nematode (Mesocriconema xenoplax), root-lesion nematode (Pratylenchus vulnus), and the vector-virus nematodes Xiphinema index and $X$. italiae (Table 2). Overall, the frequency of these nematode species in soil and root samples ranged from $34.4 \%$ (Mesocriconema xenoplax) to $1.6 \%$ (Meloidogyne arenaria) (Table 2).

Morphological studies of the perineal patterns showed typical traits for each species as described in the literature. Isozyme analysis of $M$. arenaria from
Almonte (Huelva Province) showed a characteristic double band, $M$. incognita from several localities of all three provinces studied, such us Chipiona and Sanlúcar de Barrameda (Cádiz Province), Aguilar de la Frontera, Montemayor, Montilla, Monturque, and Puente Genil (Córdoba Province), and Bonares and Niebla (Huelva Province) shared a characteristic single band, and $M$. javanica from Montemayor (Córdoba Province), and Almonte, Bollullos par del Condado and Rociana (Huelva Province) shared three characteristics bands. PCR assays using the SCAR primer pairs specific for Meloidogyne species amplified the predicted products from DNA of the reference isolates (a band of $420 \mathrm{bp}$ for $M$. arenaria, primer pair Far/Rar; 1,200 bp for $M$. incognita, primer pair Finc/Rinc; and $720 \mathrm{bp}$ for $M$. javanica, primer pair Fjav/Rjav) (44) (Fig. 1A, lane 1; Fig. 1B, lane 1; Fig. 1C, lane 1). Results of assays of the single sampled egg-laying females from Almonte (Huelva Province) confirmed the identity of $M$. arenaria (Fig. 1A, lanes 2 and 3), M. incognita for the single female samples originating from grapevine fields in several localities of the three provinces surveyed (Fig. 1B, lanes 2 to 6 ), and M. javanica for the single females sampled from different grapevine rootstocks from Montemayor (Córdoba Province), and Almonte, Bollullos par del Condado, and Rociana (Huelva Province) (Fig. 1C, lanes 2 to 5). No amplifications occurred when samples of the reference Meloidogyne species were assayed using heterologous primer pairs, and no cross amplification was observed when a given unknown sample was assayed with several primer pairs (Fig. 1A, lanes 4 to 11; Fig. 1B, lanes 7 to 11; Fig. 1C, lanes 6 to 11$)$.

Generally, no disease symptoms were observed aboveground, except in some vineyards in Huelva Province that were

Table 2. Frequency and population densities of plant-parasitic nematodes in soil and roots of grapevine rootstock sampling in different localities and provinces in southern Spain ${ }^{\mathrm{a}}$

\begin{tabular}{|c|c|c|c|c|c|c|c|}
\hline \multirow[b]{3}{*}{ Nematode species } & \multirow{3}{*}{$\begin{array}{c}\text { Overall } \\
\text { frequency }^{b}\end{array}$} & \multicolumn{2}{|c|}{ Cádiz Province } & \multicolumn{2}{|c|}{ Córdoba Province } & \multicolumn{2}{|c|}{ Huelva Province } \\
\hline & & $\begin{array}{l}\text { Nematodes/ } \\
100 \mathrm{~cm}^{3} \text { soil }\end{array}$ & $\begin{array}{c}\text { Nematodes/ } \\
\text { g root }\end{array}$ & $\begin{array}{l}\text { Nematodes/ } \\
100 \mathrm{~cm}^{3} \text { soil }\end{array}$ & $\begin{array}{c}\text { Nematodes/ } \\
\text { g root }\end{array}$ & $\begin{array}{l}\text { Nematodes/ } \\
100 \mathrm{~cm}^{3} \text { soil } \\
\end{array}$ & $\begin{array}{c}\text { Nematodes/ } \\
\text { g root }\end{array}$ \\
\hline & & Mean \pm SE & Mean \pm SE & Mean \pm SE & Mean \pm SE & Mean \pm SE & Mean \pm SE \\
\hline Amplimerlinius sp. & 3.1 & $-\mathrm{c}$ & - & $4.0^{\mathrm{d}}$ & - & 2.0 & - \\
\hline Aorolaimus perscitus & 4.7 & - & - & $58.0 \pm 76.4$ & - & 116.0 & - \\
\hline Criconemoides informis & 14.1 & $5.3 \pm 1.5$ & - & $9.5 \pm 6.2$ & - & - & - \\
\hline Gracilacus peratica & 15.6 & $24.0 \pm 18.6$ & $0.3 \pm 0.7$ & $6.7 \pm 4.7$ & $0.7 \pm 0.6$ & 3.0 & - \\
\hline Helicotylenchus digonicus & 53.1 & $39.5 \pm 39.7$ & $0.18 \pm 0.5$ & $47.0 \pm 41.4$ & $0.14 \pm 0.4$ & 7.0 & - \\
\hline H. pseudorobustus & 7.8 & $19.5 \pm 2.1$ & $0.3 \pm 0.5$ & 128.0 & - & $14.0 \pm 2.8$ & $7.1 \pm 8.1$ \\
\hline H. vulgaris & 6.3 & - & - & 4.0 & - & $20.0 \pm 9.2$ & - \\
\hline Longidorus macrosoma & 14.1 & - & - & $7.0 \pm 7.1$ & - & - & - \\
\hline Meloidogyne arenaria & 1.6 & - & - & - & - & 239.0 & 76.7 \\
\hline M. incognita & 26.6 & $169.6 \pm 142.1$ & $46.9 \pm 96.8^{\mathrm{e}}$ & $28.9 \pm 53.1$ & $359.1 \pm 894.0$ & $7.7 \pm 13.3$ & $136.5 \pm 211.5$ \\
\hline M. javanica & 14.1 & - & - & 365.0 & 33,311 & $51.4 \pm 77.6$ & $69.6 \pm 106.0$ \\
\hline Merlinius brevidens & 53.1 & $11.0 \pm 6.6$ & - & $29.4 \pm 35.8$ & - & $12.0 \pm 5.6$ & - \\
\hline M. joctus & 3.1 & - & - & $9.0 \pm 7.1$ & - & - & - \\
\hline Mesocriconema annulifer & 1.6 & 3.0 & - & - & - & - & - \\
\hline M. kirjanovae & 1.6 & - & - & - & - & 54.0 & - \\
\hline M. sphaerocephala & 7.8 & $99.0 \pm 158.6$ & - & - & - & $25.0 \pm 32.5$ & $7.1 \pm 8.1$ \\
\hline M. xenoplax & 34.4 & $201.8 \pm 157.4$ & $1.3 \pm 2.7$ & $19.1 \pm 41.2$ & - & $44.6 \pm 46.2$ & $1.4 \pm 1.6$ \\
\hline Ogma rhombosquamatum & 1.6 & - & - & - & - & - & - \\
\hline Paratrophurus loofi & 1.6 & - & - & 68.0 & - & - & - \\
\hline Paratylenchus arculatus & 6.5 & $23.3 \pm 9.1$ & $1.0 \pm 1.4$ & - & - & - & - \\
\hline P. ciccaronei & 28.1 & $35.5 \pm 55.2$ & $1.3 \pm 1.3$ & $19.3 \pm 16.9$ & $0.3 \pm 0.5$ & $19.0 \pm 12.6$ & $0.7 \pm 1.4$ \\
\hline P. microdorus & 28.1 & $24.0 \pm 24.0$ & $1.1 \pm 1.1$ & $20.1 \pm 21.7$ & $1.7 \pm 3.3$ & - & - \\
\hline Pratylenchus neglectus & 14.1 & - & - & $11.0 \pm 14.5$ & $1.3 \pm 3.5$ & 1.0 & 0.2 \\
\hline P. penetrans & 1.6 & - & - & 7.0 & - & - & - \\
\hline P. thornei & 10.9 & 24.0 & - & $7.4 \pm 6.7$ & - & - & - \\
\hline P. vulnus & 6.3 & - & - & $50.0 \pm 41.0$ & $0.4 \pm 0.6$ & $8.5 \pm 3.5$ & $7.1 \pm 8.1$ \\
\hline Rotylenchus goodeyi & 14.1 & 19.0 & - & - & - & $78.8 \pm 54.7$ & - \\
\hline R. incultus & 1.6 & - & - & 5.0 & - & - & - \\
\hline Trichodorus sp. & 6.3 & - & - & 2.0 & - & $19.0 \pm 21.9$ & - \\
\hline Tylenchorhynchus clarus & 7.8 & - & - & $11.3 \pm 4.7$ & - & 12.0 & - \\
\hline Tylenchorhynchus sp. & 15.6 & $7.6 \pm 2.1$ & - & - & - & - & - \\
\hline Xiphinema index & 12.5 & $8.8 \pm 5.6$ & - & 6.0 & - & $2.3 \pm 0.6$ & - \\
\hline X. italiae & 10.9 & 6.0 & - & - & - & $4.8 \pm 2.8$ & - \\
\hline X. pachtaicum & 79.7 & $17.5 \pm 21.9$ & - & $8.1 \pm 8.0$ & - & $9.6 \pm 5.2$ & - \\
\hline X. turcicum & 7.8 & 3.0 & - & $13.5 \pm 15.3$ & - & - & - \\
\hline Zygotylenchus guevarai & 20.3 & 7.0 & - & $16.2 \pm 14.4$ & - & $52.0 \pm 69.3$ & - \\
\hline
\end{tabular}


infested with the virus-vector nematodes $X$. index and $X$. italiae. Plants from those vineyards showed typical GFLV symptoms consisting of a yellow mosaic pattern on leaves early in the growing season and shortening of vine internodes (Fig. 2A). However, all plants infected by root-knot nematodes showed distorted feeder roots and root galls, ranging from 2 to $6 \mathrm{~mm}$ (Fig. 2B to F). The galls developed either singly or in clusters (Fig. $2 \mathrm{C}$ to $\mathrm{E}$ ).

Meloidogyne spp. were found in both soil and rootstocks from all three surveyed provinces, and they were associated mainly with sandy soils. Nematode population densities ranged from 8 to 365 eggs and second-stage juveniles (J2) per $100 \mathrm{~cm}^{3}$ of soil, and from 47 to 33 eggs and $\mathrm{J} 2$ per gram of root (Table 2). $M$. incognita was found infecting all main rootstocks used in the three provinces, including Castel 196-17, Couderc 161-49, Millardet \& Grasset 41-B, Moscatel, Paulsen 1103, Richter 110, Ruggeri 140, Rupestris du Lot, and V. riparia. Conversely, $M$. javanica occurred only in Córdoba and Huelva provinces, infecting Couderc 161-49 and Richter 110 rootstocks; and $M$. arenaria was detected only in Huelva infecting Richter 110 rootstock. Nematode soil population densities were in the range of 8 to $167 \mathrm{~J} 2$ per $100 \mathrm{~cm}^{3}$ for $M$. incognita and 51 to 365 $\mathrm{J} 2$ for M. javanica.

Mesocriconema xenoplax was found in soil and root samples from all three provinces $(34.4 \%)$. The population density of this species ranged from 19 to 202 nema-
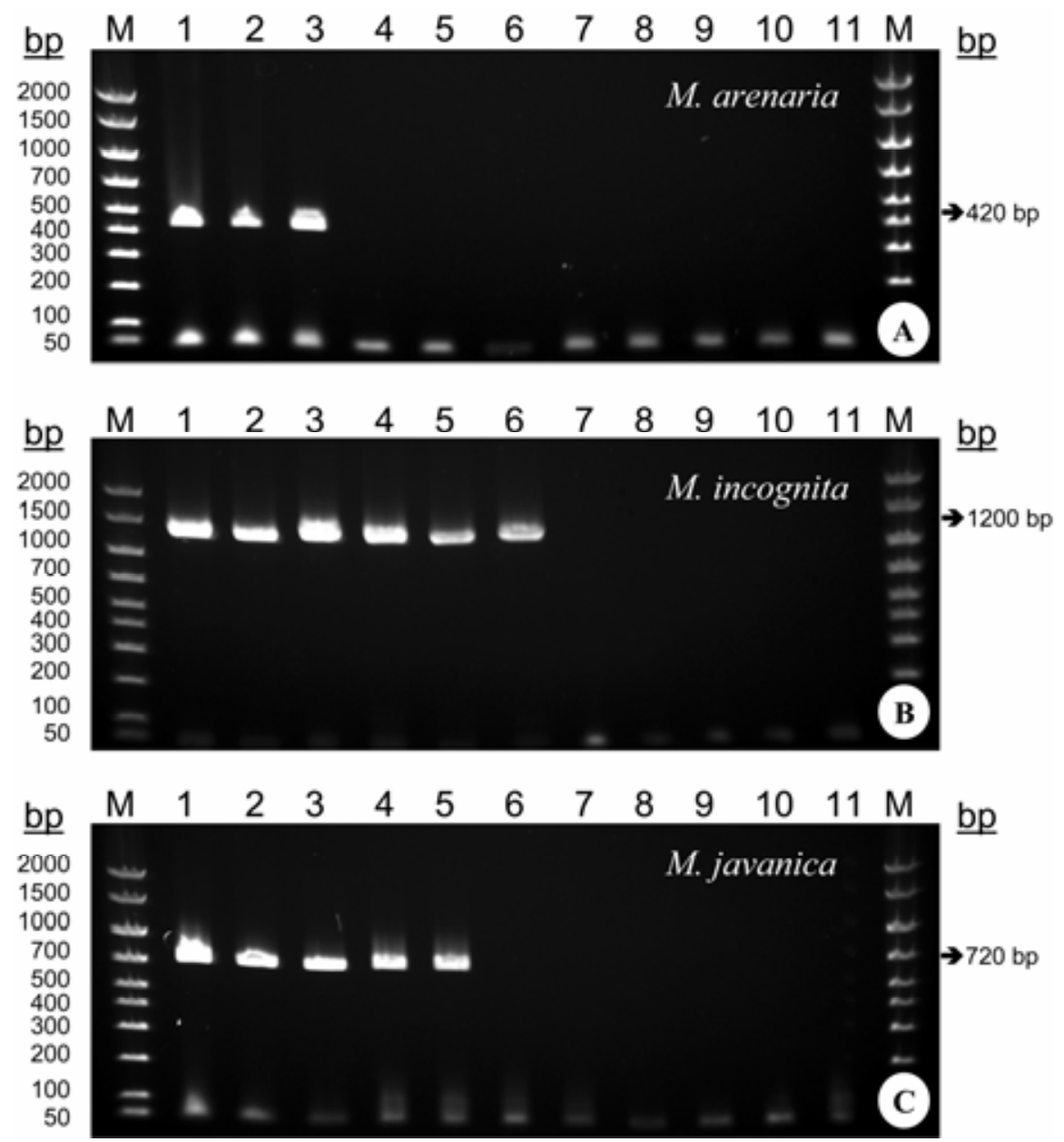

Fig. 1. A, Polymerase chain reaction (PCR) amplification product using primer pair Far/Rar and 1 to $10 \mathrm{ng}$ of template DNA of representative samples of Meloidogyne isolates: M. arenaria reference isolate from olive nurseries, lane 1; $M$. arenaria from grapevine rootstock Richter 110 from Almonte, Huelva Province, lanes 2-3; M. incognita from olive nurseries in Spain, lanes 4-7; M. javanica from potato in Malta, lanes 8-10; control (no template DNA), lane 11. B, PCR amplification product using primer pair Finc/Rinc and 1 to $10 \mathrm{ng}$ of template DNA of Meloidogyne isolates: M. incognita reference isolate from olive nurseries, lane 1; M. incognita from grapevine rootstocks sampled at Sanlúcar de Barrameda (Cádiz Province), Montilla and Montemayor (Córdoba Province), and Niebla and Bonares (Huelva Province), lanes 2-6, respectively; $M$. arenaria from olive nurseries in Southern Spain, lanes 7-8; . javanica from potato in Malta, lanes 9-10; control (no template DNA), lane 11. C, PCR amplification product using primer pair Fjav/Rjav and 1 to $10 \mathrm{ng}$ of template DNA of Meloidogyne isolates: $M$. javanica reference isolate from potato in Malta, lane 1; M. javanica from grapevine rootstocks sampled at Montemayor (Córdoba Province), and Almonte, Bollullos par del Condado, and Rociana (Huelva Province), lanes 2-5, respectively; $M$. arenaria from olive nurseries in Spain, lanes 6-7; $M$. incognita from olive nurseries in southern Spain, lanes 8-10; control (no template DNA), lane 10. todes per $100 \mathrm{~cm}^{3}$ of soil, and from 1 to 2 nematodes per gram of root. $X$. index was found in $12.5 \%$ of soil samples in all three surveyed provinces; whereas $X$. italiae was detected in Cádiz and Huelva provinces with a frequency of $10.9 \%$ (Table 2). Finally, low population densities of the root-lesion nematode $P$. vulnus were found in $6.3 \%$ of soil samples, and in roots of Ruggeri 140 rootstock in Córdoba, and Richter 110 and Rupestris du Lot rootstocks in Huelva (Table 2). Other root-lesion nematodes ( $P$. neglectus, $P$. penetrans, $P$. thornei, and $Z$. guevarai) were detected in moderate $(20.3 \%)$ to low $(1.6 \%)$ frequencies in soil and root samples (Table 2).

Other plant-parasitic nematodes that were detected in soil and rootstocks included needle (Longidorus macrosoma), dagger (X. pachtaicum and X. turcicum), spiral (Helicotylenchus spp., Rotylenchus spp.), ring (Criconemoides informis, Mesocriconema spp.), stunt (Tylenchorhynchus spp., Amplimerlinius spp.), and pin (Gracilacus peratica, Paratylenchus spp.) nematodes, but population levels were generally low (Table 2).

Histopathology. Root galls caused by root-knot nematodes occurred individually or in clusters, causing severe distortion of the entire root perimeter (Fig. 2B to E). Swellings along the root axis were spheroid in shape with a diameter as large as one and a half to twofold that of healthy roots. Usually each gall contained one female, but occasionally two to three were observed (Fig. 3B and C). Egg masses with 200 to 450 eggs mainly protruded from the roots (Fig. 2G), but sometimes were located within the root cortex (Fig. 3C). Meloidogyne infections caused alterations in cells of the root cortex, endodermis, pericycle, and vascular cylinder (Fig 3 ). In early stages of infections, J2 were found migrating through the root cortex apoplast, eventually reaching the vascular cylinder (Fig. 3D) where giant cells were induced to form.

In all Meloidogyne-infected rootstocks, the giant cells were induced adjacent to vascular tissue (Fig. 3B to I). In the typical susceptible reaction, the formation of giant cells led to extensive distortion and crushing of the vascular cylinder, as well as hyperplasic disorganization of the root cortex (Figs. 3E to I). In young Paulsen 1103 rootstocks, the giant-cell feeding site induced by $M$. incognita invaded nearly the entire stele, almost completely preventing the formation of vascular tissues (Fig. 3I). Commonly, the nematode feeding sites comprised three to five giant cells surrounding the nematode's head, but in some cases up to 11 giant cells were induced by a single female (Fig. 3I). The giant cells exhibited the characteristic cytological features of granulated cytoplasm, thickened cell walls, and variable numbers (4 to 22) of hypertrophied nuclei and nucleoli 
(Fig. 3H and I). In some cases, necrotic areas were evident in the root cortical parenchyma near the body of the nematode (Fig. 3B, C, and F).

\section{DISCUSSION}

The primary goal of this study was to determine the extent of soil infestation and rootstock infection by plant-parasitic nematodes in commercial vineyards of key grapevine-growing areas of southern Spain. Among the 36 species of plantparasitic nematodes diagnosed in the study,
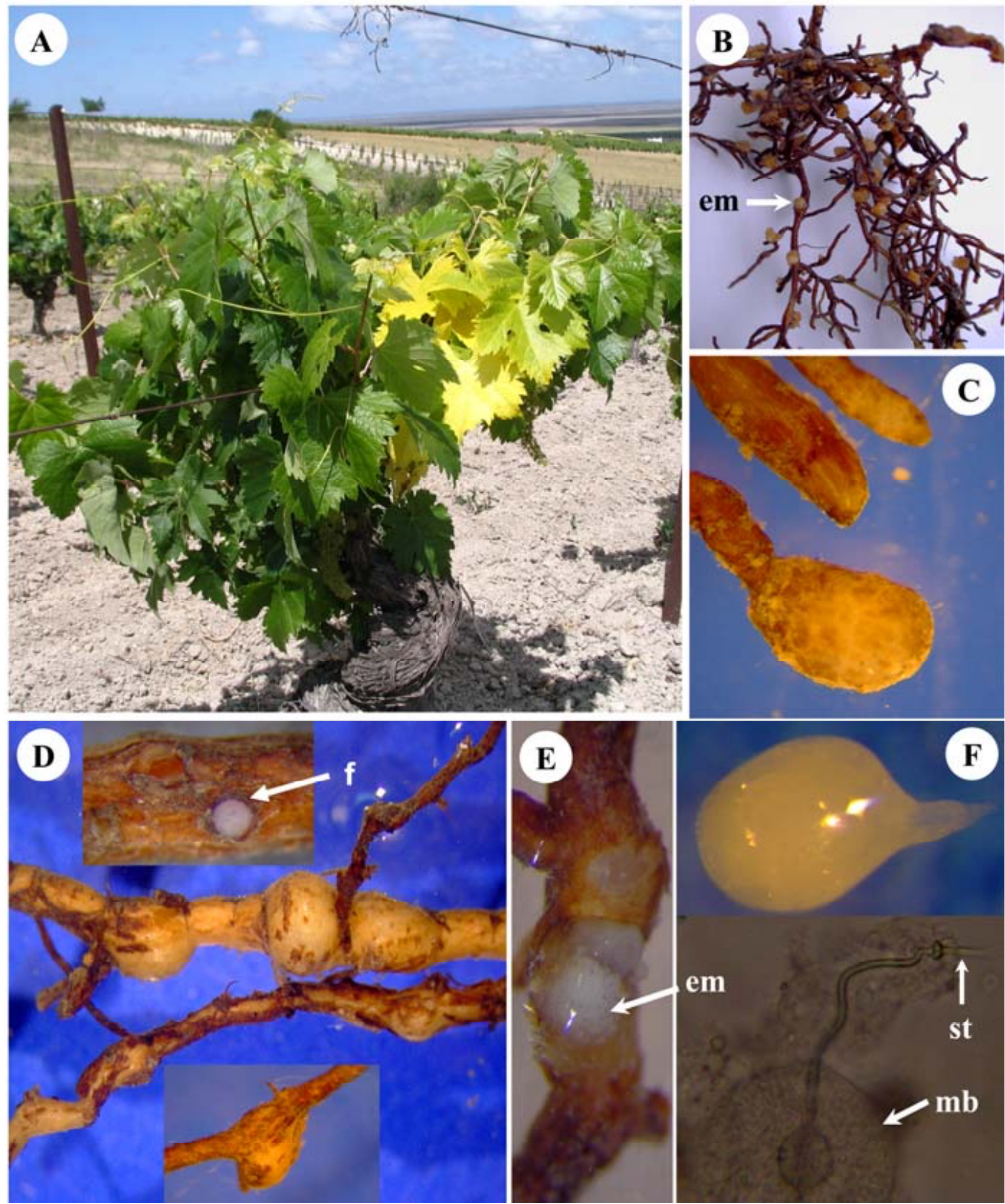

Fig. 2. A, Typical brilliant yellow mosaic pattern shown in spring on leaves of a grapevine infected by a chromogenic virus strain in a commercial vineyard at Trebujena, Cádiz Province. B, Root system of grapevine rootstock Millardet \& Grasset 41B severely infected by Meloidogyne incognita showing nodulation and abundant egg masses (em). C, Apical gall of grapevine rootstock Richter 110 induced by M. javanica. D and E, Details of galls induced by M. in cognita in intermediate root zones of several grapevine rootstocks showing adult females (glossy white masses). F, Entire female of $M$. incognita and detail of dissected median bulb (mb) and stylet (st). 

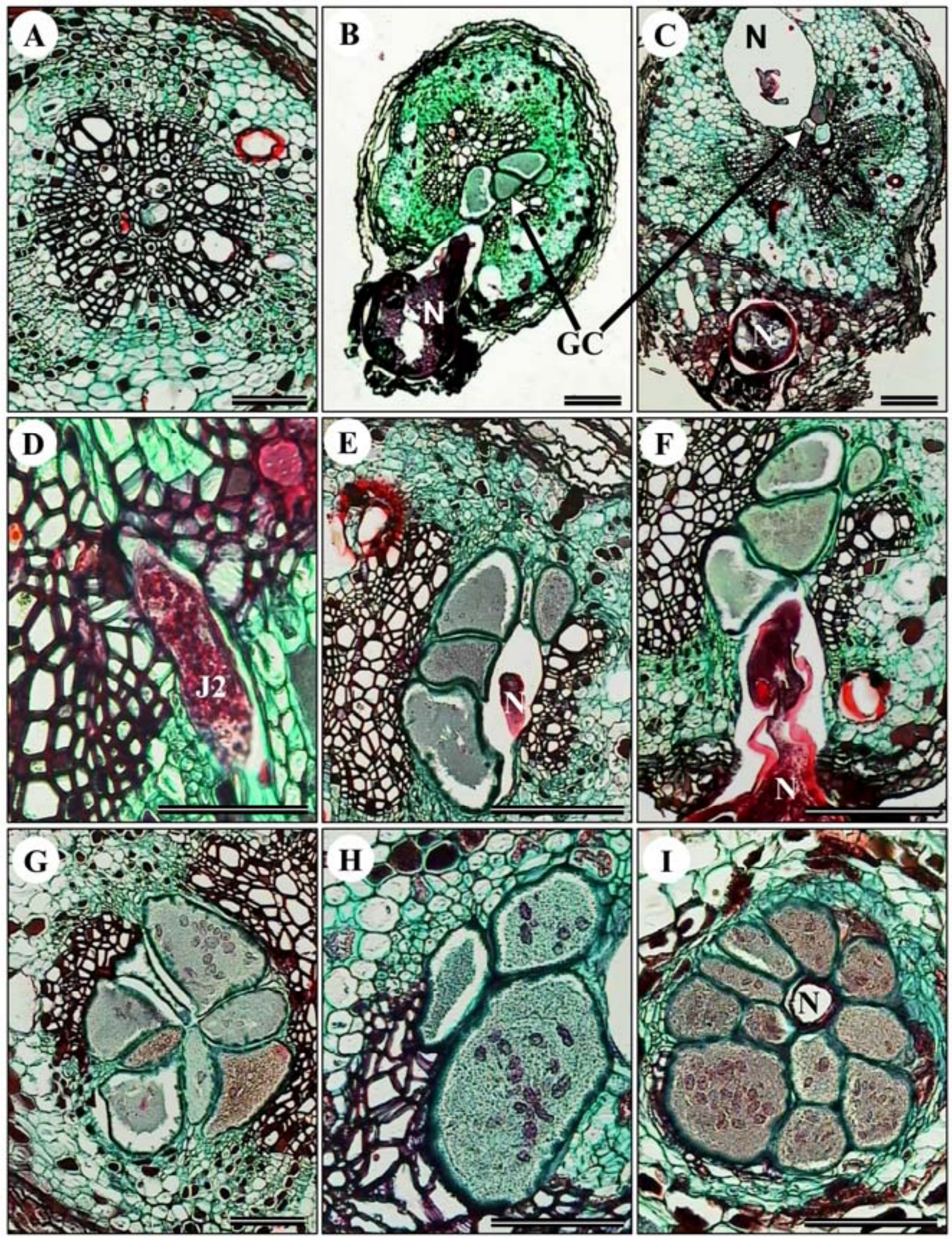

Fig. 3. A, Transverse section of a nonsymptomatic area of a young grapevine root of rootstock Richter 110, showing regular distribution and size of xylem and cortical parenchyma. B and C, Transverse sections of roots of grapevine rootstocks Richter 110 and Couderc 161-49, respectively, infected by Meloidogyne incognita. Feeding by the nematode female (N) has stimulated the formation of giant cells (GC) and disrupted the cortex and vascular tissue. D, Transverse section of grapevine root of rootstock Millardet \& Grasset 41B showing an early infection by M. incognita. The second-stage juvenile (J2) was observed migrating in the apoplast at the junction between the cortex and the vascular cylinder. E, Transverse sections of grapevine roots of rootstock Rupestris du Lot showing mature infections by adult females $(\mathrm{N})$ of $M$. incognita. F, Transverse sections of grapevine roots of rootstock Ritcher 110 showing mature infections by adult nematode females $(\mathrm{N})$ of $M$. arenaria. G, Transverse section of grapevine root of rootstock Richter 110 showing mature infection by adult female $(\mathrm{N})$ of $M$. javanica. $\mathbf{H}$ and I, Higher magnifications of feeding sites on root of grapevine rootstocks Moscatel and Paulsen 1103, respectively, induced by $M$. incognita. All scale bars $20 \mu \mathrm{m}$. 
six species, Mesocriconema xenoplax, Meloidogyne arenaria, M. incognita, $M$. javanica, $X$. index, $X$. italiae, and Pratylenchus vulnus have been reported to cause significant economic losses in other grapevine areas of the world (6). Moreover, for three of these species, Mesocriconema xenoplax, Meloidogyne incognita, and $M$. javanica, the population densities ranged from moderate to high. Particularly, Mesocriconema xenoplax has been found widely distributed in southern Spain, often occurring at population densities exceeding the levels reported to damage grapevine (36). Feeding of $M$. xenoplax on grapevine was reported to cause rapid darkening and destruction of root tissues, thus resulting in stunted root systems with a few feeder roots (36). The threshold population density of Meloidogyne spp. reported to cause yield losses in grapevine is 50 eggs and $\mathrm{J} 2 / 100 \mathrm{~cm}^{3}$ of soil (4). Therefore, the soil population densities of Meloidogyne spp. found in the surveyed vineyards are large enough (mean population of 144 eggs and $J 2 / 100 \mathrm{~cm}^{3}$ of soil) to severely affect grapevine production under field conditions of southern Spain.

No estimates have been reported of direct grapevine yield losses due to infection by the dagger nematodes, $X$. index and $X$. italiae, under field conditions. Those nematodes, however, can transmit GFLV (5), reducing the lifespan of vineyards by about 12 to 20 years (33). Consequently, they should be considered a serious threat to grapevine production in southern Spain, especially as the presence of GFLV was clearly evidenced by the presence of plants exhibiting symptoms. Accordingly, these data indicate that further surveys should be carried out to determine the importance of infections by GFLV or other viruses in grapevines in southern Spain. This would allow establishing quarantine measures to assure that grapevine rootstocks are free of virus. Other nematodes found in most of the surveyed vineyards in southern Spain, such as spiral, stunt, ring, and pin nematodes, as well as the root-lesion nematodes $P$. neglectus, $P$. thornei, and Z. guevarai, are common parasites of monocotyledonous and dicotyledonous weeds and are not expected to cause important economic damage to grapevines.

The absence of infestations by the citrus nematode ( $T$. semipenetrans) in the surveyed vineyards could be related to these vineyards being far away from the nearest citrus production area. The absence could also be due, at least in part, to resistance of some grapevine rootstocks (such as Richter 110, SO4) to that nematode $(1,25)$ since $T$. semipenetrans has been reported infesting citrus orchards in southern Spain (29) and the three biotypes of this nematode can reproduce in grapevines (40).

Histopathological observations of Meloidogyne-infected rootstocks revealed typical alterations in root cell structure and morphology which would negatively affect the efficacy of nutrient and water uptake and transport by infected roots (18). Generally, the high numbers of eggs and $\mathrm{J} 2$ extracted from those rootstocks indicate that they are good to excellent hosts of the nematodes. The development and parasitic habit of Meloidogyne spp. that we observed in naturally infected grapevine rootstocks in southern Spain were similar to those found in Moscatel rootstocks artificially infected with $M$. javanica $(10,23)$, and Vitis vinifera cv. Thompson seedless artificially infected with $M$. incognita (15). Also, the occurrence of the nematode egg masses with numerous eggs formed within root tissues was similar to infections in olive planting stocks in southern Spain (27). The majority of the nematode egg masses, however, protruded from the root tissues, a situation which could further facilitate secondary infections by the nematodes by favoring their dispersal within and between vineyards by agricultural operations and movement of machinery. The histopathological responses, and the numerous egg masses and $\mathrm{J} 2$ stages observed in roots and rhizosphere, indicate that the nematodes developed and reproduced extensively in the major grapevine rootstocks grown in southern Spain. Consequently, those rootstocks should be considered good or very good hosts for Meloidogyne spp., evidence which, furthermore, should be taken into account for future field replants.

Overall, these results emphasize the importance of determining the presence of Meloidogyne spp. infestations in the soil, as well as using resistant rootstocks in southern Spain. The present study shows that rootstocks (such as Paulsen 1103, Richter 110, Rupestris du Lot, SO4) that were previously considered moderately resistant to $M$. arenaria, $M$. incognita, and $M$. javanica $(11,26,28)$ should be considered susceptible under Spanish field conditions. Therefore, these reportedly resistant rootstocks cannot be considered effective against the Meloidogyne spp. populations occurring in southern Spain. Also, care should be taken with respect to Meloidogyne spp. populations present in other geographical areas. Whether these populations are newly damaging and/or resistance-breaking ones selected from the indigenous populations (2) needs to be ascertained through experiments under controlled conditions. Variation in virulence of populations of $M$. incognita on grapevine rootstocks has also been reported previously (3). Moreover, the susceptible response of the uncharacterized accessions of $V$. berlandieri and $V$. riparia rootstocks to infection by $M$. incognita and $M$. javanica agrees with results reported by Walker et al. (42), who found these rootstocks susceptible or only partially resistant to $M$. incognita.
In conclusion, these results demonstrate the importance of studying natural infections by root-knot nematodes in grapevine rootstocks in infested areas. Also, the information obtained highlights the need for proper nematode identification coupled with analysis of rootstock responses to nematode infection, to facilitate the selection of tolerant or resistant cultivars and help to lessen dependence on nematicides. Finally, the performance of rootstocks previously reported to possess a degree of resistance to some species of Meloidogyne must be evaluated under the growing conditions prevailing in southern Spain, and in response to locally occurring nematode species or isolates, before they can be considered resistant and are planted extensively.

\section{ACKNOWLEDGMENTS}

This research was supported in part by grant P06-AGR1360 from Consejería de Innovación, Ciencia y Empresa (CICE), Junta de Andalucía. The research stay in Spain of D. Téliz was supported by a grant from the University of Córdoba, Spain. The authors thank C. Weiland for his help in the survey of Huelva Province, J. A. Navas-Cortés for reviewing the manuscript prior to submission, and J. Martín-Barbarroja and E. García-Cuevas Agredano for technical assistance. B. B. Landa was recipient of a Ramón y Cajal grant from Ministerio de Educación y Ciencia of Spain.

\section{LITERATURE CITED}

1. Aballay, E., and Navarro, A. 2005. Tolerance of some grapevine rootstocks to Tylenchulus semipenetrans Cobb 1914 in Chile. Agric. Técnica 65:319-322.

2. Anwar, S. A., and McKenry, M. V. 2002. Developmental response of a resistance-breaking population of Meloidogyne arenaria on Vitis spp. J. Nematol. 34:28-33.

3. Anwar, S. A., McKenry, M. V., and Faddoul, J 2000. Reproductive variability of field populations of Meloidogyne spp. on grape rootstocks. J. Nematol. 32:265-270.

4. Anwar, S. A., and Van Gundy, S. D. 1989. Influence of four nematodes on root and shoot growth parameters in grape. J. Nematol. 21:276-283.

5. Bird, G., Diamond, C., Warner, F., and Davenport, J. 1994. Distribution and regulation of Meloidogyne nataliei. J. Nematol. 26:727-730.

6. Brown, D. J., Dalmasso, A., and Trudgill, D. L. 1993. Nematode pests of soft fruits and vines. Pages 427-462 in: Plant-Parasitic Nematodes in Temperate Agriculture. K. Evans, D. L. Trudgill, and J. M. Webster, eds. CAB International, Wallingford, UK.

7. Carneiro, R. M. D. G., Randig, O., Almeida, M. R. A., and Gomes, A. C. M. M. 2004. Additional information on Meloidogyne ethiopica Whitehead, 1968 (Tylenchida: Meloidogynidae), a root-knot nematode parasitising kiwi fruit and grape-vine from Brazil and Chile Nematology 6:109-123.

8. Castillo, P., Vovlas, N., Subbotin, S., and Troccoli, A. 2003. A new root-knot nematode, Meloidogyne baetica $\mathrm{n}$. sp. (Nematoda: Heteroderidae), parasitizing wild olive in Southern Spain. Phytopathology 93:1093-1102.

9. Coolen, W. A. 1979. Methods for extraction of Meloidogyne spp. and other nematodes from roots and soil. Pages 317-329 in: Root-Knot Nematodes (Meloidogyne species). Systematics, Biology, and Control. F. Lamberti and C. E. Taylor, eds. Academic Press, New York.

10. Doucet, M., Ponce de León, E. J., and Bustos, E. 1984. Alteraciones histológicas en Vitis vi- 
nifera variedad Moscatel por Meloidogyne javanica (Treub, 1885) Chitwood, 1949. Rev. Invest. Agropec. INTA 14:107-113.

11. Edwards, M. 1989. Resistance and tolerance of grapevine rootstocks to plant parasitic nematodes in vineyards in north-east Victoria. Aust. J. Exp. Agric. 29:129-131.

12. Esbenshade, P. R., and Triantaphyllou, A. C. 1985. Identification of Meloidogyne species employing enzyme phenotypes as differentiating characters. Pages 135-140 in: An Advanced Treatise on Meloidogyne. Vol. 2. Methodology. K. R. Barker, C. C. Carter, and J. N. Sasser, eds. North Carolina State University Graphics, Raleigh.

13. FAO, 2005. Faostat Database Collections. FAO. Online publication.

14. Ferris, H., and McKenry, M. V. 1975. Relationship of grapevine yield and growth to nematode densities. J. Nematol. 7:295-304.

15. Hafez, S. L., and Sundararaj, P. 2000. Host parasite interaction of Meloidogyne incognita and Vitis vinifera under green house conditions. Int. J. Nematol. 10:71-74.

16. Hartman, K. M., and Sasser, J. N. 1985. Identification of Meloidogyne species on the basis of differential host test and perineal pattern morphology. Pages 69-77 in: An Advanced Treatise on Meloidogyne. Vol. 2. Methodology. K. R. Barker, C. C. Carter, and J. N. Sasser, eds. North Carolina State University Graphics, Raleigh.

17. Hussey, R. S., and Barker, K. R. 1973. A comparison of methods of collecting inocula of Meloidogyne spp., including a new technique. Plant Dis. Rep. 57:1025-1028.

18. Hussey, R. S., and Williamson, V. M. 1997. Physiological and molecular aspects of nematode parasitism. Pages 87-108 in: Plant and Nematode Interactions. K. R. Barker, G. A. Pederson, and G. L. Windham, eds. American Society of Agronomy, Madison, WI.

19. Jensen, W. A. 1962. Botanical Histochemistry. W.H. Freeman and Co., San Francisco, CA.

20. Jenser, G., Debaj, K. H., and Lehoczky, J. 1991. The effect of the northern root-knot nematode (Meloidogyne hapla Chitwood) as a possible cause of unsuccessful replanting of vineyards on sandy soil. Novenyvedelem 27:62-65.

21. Jepson, S. B. 1987. Identification of root-knot nematodes. CAB International, Wallingford, UK.

22. Kleynhans, K. P. N. 1993. Meloidogyne hispanica Hirchmann, 1986 and M. ethiopica Whitehead, 1968 in South Africa (Nemata: Heteroderidae). Phytophylactica 25:283-288.

23. Lamberti, F., Vovlas, N., and Hugo, H. J. 1990. Damage by Meloidogyne javanica on vines in south Africa. Nematol. Mediterr. 18:1-3.

24. McKenry, M. V. 1987. Control strategies in high-value crops. Pages 329-349 in: Principles and Practice of Nematode Control in Crops. R. H. Brown and B. R. Kerry, eds. Academic Press, Orlando, FL.

25. McKenry, M. V., and Anwar, S. A. 2006. Nematode and grape rootstock interactions including an improved understanding of tolerance. J. Nematol. 38:312-318

26. Mor, M., Bar-Eyal, M., Gottlieb, Y., and Harcavi, E. 2003. Grape rootstocks resistant or tolerant to the root-knot nematode species Meloidogyne javanica and $M$. incognita. Phytoparasitica 31:414.

27. Nico, A. I., Rapoport, H. F., Jiménez-Díaz, R. M., and Castillo, P. 2002. Incidence and population density of plant-parasitic nematodes associated with olive planting stocks at nurseries in Southern Spain. Plant Dis. 86:1075-1079.

28. Nicol, J. M., Stirling, G. R., Rose, B. J., May, P., and Van Heeswijck, R. 1999. Impact of nematodes on grapevine growth and productivity: Current knowledge and future directions, with special reference to Australian viticulture. Aust. J. Grape Wine Res. 5:109-127.

29. Peña Santiago, R., Castillo, P., Escuer, M., Guerrero, P., Talavera, M., and Vieira, P. 2004. Tylenchid species (Nematoda, Tylenchida) recorded in the Iberian Peninsula and the Balearic Islands: A Compendium. Collection "Monographic Papers on Nematology", Servicio de Publicaciones, Universidad de Jaén, Jaén, Spain.

30. Pinkerton, J. N., Schreiner, R. P., Ivors, K. L., and Vasconcelos, M. C. 2004. Effects of Mesocriconema xenoplax on Vitis vinifera and Associated Mycorrhizal Fungi. J. Nematol. 36:193-201.

31. Pinochet, J., and Cisneros, T. 1986. Seasonal fluctuations of nematode populations in three Spanish vineyards. Rev. Nématol. 9:391-398.

32. Quader, M., Riley, I. T., and Walker, G. E. 2001. Distribution pattern of root-knot nema- todes (Meloidogyne spp.) in South Australian vineyards. Australas. Plant Pathol. 30:357-360.

33. Raski, D. J. 1988. Parasites of grapes. Pages 55-59 in: Compendium of Grape Diseases. R. C. Pearson and A. C. Goheen, eds. American Phytopathological Society, St. Paul, MN.

34. Raski, D. J., Hart, W. H., and Kasimatis, A. N. 1973. Nematodes and their control in vineyards. Calif. Agric. Exp. Stn. Circ. 533.

35. Salmerón Parra, T., Andreu López, M., and Tobar Jiménez, A. 1986. Observaciones sobre el "amerinado" de los viñedos del condado de Huelva. Bol. Serv. Plagas 12:143-146.

36. Santo, G. S., and Bolander, W. J. 1977. Effects of Macroposthonia xenoplax on the growth of concord grape. J. Nematol. 9:215-217.

37. Seinhorst, J. W. 1962. On the killing, fixation and transferring to glycerine of the nematodes. Nematologica 8:29-32.

38. Stirling, G. R., and Cirami, R. M. 1984. Resistance and tolerance of grape rootstocks to South Australian populations of root-knot nematode. Aust. J. Exp. Agric. Anim. Husbandry 24:277-282.

39. Stirling, G. R., Stanton, J. M., and Marshall, J. 1992. The importance of plant-parasitic nematodes to Australian and New Zealand agriculture. Australas. Plant Pathol. 24:104-115.

40. Verdejo Lucas, S., Sorribas, F. J., Pons, J Forner, J. B., and Alcaide, A. 1997. The mediterranean biotypes of Tylenchus semipenetrans in Spanish citrus orchards. Fund. Appl. Nematol. 20:399-404

41. Vovlas, N., Midsuf, D., Landa, B. B., and Castillo, P. 2005. Pathogenicity of the rootknot nematode Meloidogyne javanica on potato. Plant Pathol. 54:657-664.

42. Walker, M. A., Ferris, H., and Eyre, M. 1994 Resistance in Vitis and Muscadinias species to Meloidogyne incognita. Plant Dis. 78:10551058 .

43. Weiland-Ardaiz, C., and Pérez Camacho, F. 1995. Nematodes vectors of virus in the 'Denominación De Origen Condado de Huelva', Spain. Acta Hortic. 388:31-35.

44. Zijlstra, C., Donkers-Venne, D. T. H. M., and Fargette, M. 2000. Identification of Meloidogyne incognita, $M$. javanica and $M$. arenaria using sequence characterised amplified region (SCAR) based PCR assays. Nematology 2:847-853. 